\title{
Multi-Residue Levels of Persistent Organochlorine Pesticides in Edible Vegetables: A Human Health Risk Assessment
}

\author{
Samuel Oluyemi Adefemi, Samuel Sunday Asaolu, Olayinka Abidemi Ibigbami*, \\ Joshua Iseoluwa Orege, Mayowa Akeem Azeez, Abiodun Folasade Akinsola \\ Department of Chemistry, Ekiti State University, Ado-Ekiti, Nigeria \\ Email: adefemisamuel@yahoo.com, ssasaolu@yahoo.com, *olayinkaibigbami@yahoo.co.uk, Joshua.orege@eksu.edu.ng, \\ mayowa.azeez@eksu.edu.ng, akinsolaf87@gmail.com
}

How to cite this paper: Adefemi, S.O., Asaolu, S.S., Ibigbami, O.A., Orege, J.I., Azeez, M.A. and Akinsola, A.F. (2018) Multi-Residue Levels of Persistent Organochlorine Pesticides in Edible Vegetables: A Human Health Risk Assessment. Journal of Agricultural Chemistry and Environment, 7, 143-152.

https://doi.org/10.4236/jacen.2018.74013

Received: September 23, 2018

Accepted: November 3, 2018

Published: November 6, 2018

Copyright (c) 2018 by authors and Scientific Research Publishing Inc. This work is licensed under the Creative Commons Attribution International License (CC BY 4.0).

http://creativecommons.org/licenses/by/4.0/ (C) (i) Open Access

\begin{abstract}
Background: This study evaluates the quantitative assessment of persistent organochorine pesticide (OCPs) residues in vegetables (Senecio biafrae) from four selected cocoa plantations in Ekiti State, Nigeria. Methods: The pesticides were extracted from the vegetable samples by using USEPA 3500C method and later clean-up on activated silica gel. The pesticides residues in the samples were determined using Gas Chromatography coupled with Electron Capture Detector (GC-ECD). Results: The results showed that the analyzed samples were contaminated with ten OCPs. The mean OCPs concentration ranged from $\mathrm{ND}-0.399 \mathrm{mg} / \mathrm{kg}$ to $\mathrm{ND}-0.379 \mathrm{mg} / \mathrm{kg}$ during the wet and dry seasons respectively. $\alpha$-BHC, $\beta$-BHC, $p$, $p^{\prime}$-DDE, dieldrin, endrin, endosulfan sulphate and methoxychlor were not detected in the samples. Pesticides such as aldrin, endosulfan II, endrin aldehyde and heptachlor slightly exceeded their maximum residue limit. Conclusion: The hazard indices (HI) of heptachlor, endosulfan I, endosulfan II, aldrin, heptachlor-epoxide and $p$, $p$-DDT exceeded 1 and thus pose likely potential non-carcinogenic health risk.
\end{abstract}

\section{Keywords}

Organochlorine Pesticides, Vegetables, Risk, Residues, Gas Chromatography

\section{Introduction}

Vegetables are fresh and edible portion of herbaceous plants, which can be eaten raw or cooked [1] [2]. They are valuable sources of nutrients such as protein, minerals, vitamins, fibres and other nutrients, which are usually in short supply 
in daily diet [3]. Vegetables are the second major food group consumed after cereals and their products in West Africa [4]. In Nigeria, leafy vegetables are relatively available and affordable particularly in rainy season [5].

Senecio biafrae (locally called "Wórowo" in Yoruba language) is a leafy vegetable grown in large quantity as undercover in tree crop plantation. The nutritional quality of Senecio biafrae has been reported by Dairo and Adanlawo [6]. It is a wild climber that twines on woody plants. It is indigenous to West Africa and mostly found within cocoa farms in South-western Nigeria. Insect pests and diseases pose a major challenge to the production of crop including cocoa, resulting in adverse consequences of the economy [7], particularly food insecurity. During dry season, Senecio biafrae is susceptible to variegated locusts (Zonocerus variegatus) and green aphid between January and April [8]. However, in response to these seasonal problems, many farmers make use of pesticides in an attempt to reduce the evasion of insect pests and diseases on crop; an excess amount of pesticides including organochlorines are sometimes applied on farms. The excessive use of these pesticides has resulted in the presence of pesticide residues in the cocoa farm produce [9].

Organochlorine pesticides (OCPs) are commonly used by farmers because of their cost effectiveness and their broad-spectrum activity [10]. However, their residues still appear as pollutants in food as well as the environment because of their high toxicity and persistent nature [10] [11]. They accumulate in the environment and food [12] and their accumulation is still a major concern. Research data available have indicated the presence of pesticide residues in vegetables [13] [14] [15] [16]. The consumption of these vegetables containing pesticide residues could constitute major health risk to consumers.

In response to the increase in the use of pesticides on crops globally and their health effects, there has been establishment of maximum residue limits by national and international food safety authorities for all foods. Exposure to low concentration of OCPs over a long period of time may lead to a substantial body burden of the chemicals [17]. OCPs are known to have a wide range of both acute and chronic health effect such as cancer, neurological damage and birth defects. Many OCPs are also suspected as endocrine disruptors [18]. Therefore, this research is aimed at determining the multi-residue levels of OCPs in vegetables (Senecio biafrae) grown in selected cocoa farms in Ekiti State and, to ascertain if their residual levels are within the respective permissible level and also determine the associated possible potential human health risk to the consumers.

\section{Materials and Methods}

\subsection{Sampling}

The vegetable (Senecio biafrae) were sampled from four different cocoa plantations in Ise, Ire, Ido and Emure towns in Ekiti State, South-western Nigeria. In each collection, two to three different samples were randomly collected and combined to make a composite sample. Two composite vegetable samples were 
collected in each farm in the month June and December, 2015 for both wet and dry seasons respectively. The collected samples were immediately stored in labelled bags and transported to the laboratory where they were kept refrigerated at $4^{\circ} \mathrm{C}$ for about 22 hours. The samples were later washed with deionized water, air-dried, ground by agate mortar and later mixed with an Excella Mixer blender. The samples were then extracted and analyzed for the presence of OCP residues.

\subsection{Extraction and Clean-Up of the Pesticide Residue}

The extraction of organochlorine pesticides from the vegetable samples was carried out by EPA 3500C method as described by USEPA [19]. About $10 \mathrm{~g}$ of each sample and $10 \mathrm{~g}$ of anhydrous sodium sulphate were mixed in a pre-cleaned 250 $\mathrm{ml}$ conical flask. Forty millilitre $(40 \mathrm{ml})$ mixtures of acetone and $n$-hexane $(1: 1$ $\mathrm{v} / \mathrm{v})$ were added to the sample. This was followed by sonication in a high frequency ultrasonic bath for $15 \mathrm{~min}$ at $40^{\circ} \mathrm{C}$. The extract was then decanted into a round bottom flask. The extraction process was repeated with an additional $20 \mathrm{ml}$ (acetone and $n$-hexane mixture), sonicated and allowed to settle before been decanted into the same round bottom flask. The combined extracts were concentrated to $2 \mathrm{ml}$ using rotary evaporator. The extract was re-dissolved in $5 \mathrm{ml}$ $n$-hexane and again concentrated to $2 \mathrm{ml}$ in a rotary evaporator at $40^{\circ} \mathrm{C}$.

The clean-up involved the use of a column of about $15 \mathrm{~cm}$ (length) $\times 1 \mathrm{~cm}$ (internal diameter) packed with $2 \mathrm{~g}$ of activated silica gel and $1 \mathrm{~g}$ anhydrous $\mathrm{Na}_{2} \mathrm{SO}_{4}$. The column was conditioned with $15 \mathrm{ml} n$-hexane prior to the clean-up. The extracts were run through the column and eluted with $20 \mathrm{ml} n$-hexane and diethyl ether mixture $(1: 1 \mathrm{v} / \mathrm{v})$. The eluate was concentrated to dryness on the rotary evaporator and recovered into $2 \mathrm{ml} n$-hexane. The final extract was transferred into vials for subsequent injection into the GC.

\subsection{Gas Chromatographic Operating Condition}

The gas chromatography conditions for the analysis were as follows: GC model: Agilent 7890A coupled with electron capture detector (GC-ECD); injector and detector temperature were $250^{\circ} \mathrm{C}$ and $290^{\circ} \mathrm{C}$ (held for $5 \mathrm{~min}$ ); the purge activation time was $30 \mathrm{~s}$; inlet mode: splitless with flow rate of $19.6 \mathrm{ml} / \mathrm{min}$; carrier gas: nitrogen at $30 \mathrm{ml} / \mathrm{min}$; inlet temperature: $250^{\circ} \mathrm{C}$; column type: $\mathrm{DB}-17$ fused silica capillary column; column dimension: $30 \mathrm{~m} \times 0.32 \mathrm{~mm} \times 0.25 \mu \mathrm{m}$ film thickness; oven condition: initial temperature at $60^{\circ} \mathrm{C}$ for 1 minute and continued at $20^{\circ} \mathrm{C} / \mathrm{min}$ to $150^{\circ} \mathrm{C}$ at $5^{\circ} \mathrm{C} / \mathrm{min}$ to $280^{\circ} \mathrm{C}$ held for $4 \mathrm{~min}$. The total run time was $22 \mathrm{~min}$.

\subsection{Risk Assessment}

Health risk estimations were done based on the integration of pesticide analysis data, and exposure assumptions. The assumptions were made based on the United State Environmental Protection Agency's guidelines [20]. 
The estimated daily intake (EDI) of the various pesticides $\left(\mathrm{mg} \cdot \mathrm{kg}^{-1} \cdot \mathrm{day}^{-1}\right)$ were calculated using Equation (1)

$$
\mathrm{EDI}=\frac{C_{P} \times C R_{v}}{B_{w^{c}}}
$$

where $C R_{v}$ is the vegetable consumption rate $\left(\mathrm{kg} \cdot \mathrm{day}^{-1}\right)$ in Nigeria, $C_{P}$ is the mean concentration of pesticide residues $\left(\mathrm{mg} \cdot \mathrm{kg}^{-1}\right)$ in the vegetable samples and $B_{w^{c}}$ is the average body weight $(\mathrm{kg})$ of the consumers; 30 and $60 \mathrm{~kg}$ for children and adult respectively [21]. The consumption rate for vegetables according to FAO [22] in Nigeria is $0.165 \mathrm{mg} / \mathrm{kg} /$ day.

The hazard index (HI) is a function of the estimated daily intake. To estimate the risk of non-carcinogenic effect on consumers, the hazard index was calculated by dividing the estimated daily intake (EDI) by their corresponding acceptable daily intake (ADI) as shown in Equation (2). The available daily intake is a measure of the toxicity of a substance by long term and repeated ingestion. The available daily intakes (ADI) for the pesticide are shown in Table 3 [23]. An $\mathrm{HI}>1$, indicates a non-carcinogenic risk [24].

$$
\mathrm{HI}=\frac{\mathrm{EDI}}{\mathrm{ADI}}
$$

The combined hazard index (CHI) indicates the interactive and/or additive effects upon the exposure of two or more pollutants [25]. The US EPA [25] has been used to estimate risk posed by a group of pesticides that act by a common mechanism or that are toxicologically similar [26]. The combined hazard index is determined using Equation (3).

$$
\mathrm{CHI}=\frac{E_{1}}{A_{1}}+\frac{E_{2}}{A_{2}}+\cdots+\frac{E_{i}}{A_{i}}=\sum_{i=1}^{n} \frac{E_{i}}{A_{i}}
$$

where, $E_{1}, E_{2}, E_{n}$ and $E_{i}$ are the estimated daily intakes of each individual pesticide in a mixture of $\mathrm{n}$ pesticides in the food sample, whereas $A_{1}, A_{2}, A_{n}$ and $A_{i}$ are the acceptable daily intakes (ADIs) for each pesticide [27].

\section{Results and Discussion}

The Mean concentrations of OCPs residues in the vegetable samples from the selected cocoa plantations for both rainy and dry seasons were depicted in Table 1 and Table 2 respectively. The results showed that all the analyzed samples were contaminated with two or more pesticides with concentration ranges of $\mathrm{ND}-0.399$ and ND$-0.379 \mathrm{mg} / \mathrm{kg}$ for rainy and dry seasons respectively. Out of the seventeen considered OCPs, ten were found in the samples, where $p$, $p$-DDT, heptachlor and aldrin remained most predominant pesticides. $\alpha$-BHC, $\beta$-BHC, $p, p^{\prime}$-DDE, dieldrin, endrin, endosulfan sulphate and methoxychlor were below detection limit in all the samples. Ire samples were observed to be more contaminated than other farms. Their high level of pesticides residues could be due to the age of the farm, the concentration of the pesticides as prepared by farmers, the level of OCPs in the soils, among many other factors. 
Table 1. Mean concentration $(\mathrm{mg} / \mathrm{kg})$ of OCPs residues in vegetables from the selected cocoa farms in Ekiti State (rainy season).

\begin{tabular}{cccccc}
\hline OCPs & ISE & IRE & IDO & EMURE & MRL \\
\hline Alpha-BHC & $\mathrm{ND}$ & $\mathrm{ND}$ & $\mathrm{ND}$ & $\mathrm{ND}$ & 0.02 \\
Beta-BHC & $\mathrm{ND}$ & $\mathrm{ND}$ & $\mathrm{ND}$ & $\mathrm{ND}$ & 0.02 \\
Heptachlor & $\mathrm{ND}$ & $\mathrm{ND}$ & $0.035 \pm 0.034$ & $0.030 \pm 0.030$ & 0.02 \\
Aldrin & $0.299 \pm 0.262$ & $\mathrm{ND}$ & $0.068 \pm 0.068$ & $0.048 \pm 0.049$ & 0.05 \\
Gamma-BHC & $\mathrm{ND}$ & $\mathrm{ND}$ & $\mathrm{ND}$ & $\mathrm{ND}$ & 0.02 \\
Delta-BHC & $0.004 \pm 0.004$ & $0.026 \pm 0.011$ & $0.080 \pm 0.066$ & $\mathrm{ND}$ & 1.00 \\
Heptachlor epoxide & $0.004 \pm 0.004$ & $\mathrm{ND}$ & $\mathrm{ND}$ & $\mathrm{ND}$ & 0.02 \\
Endosulfan I & $0.067 \pm 0.065$ & $0.005 \pm 0.005$ & $\mathrm{ND}$ & $0.034 \pm 0.034$ & 0.10 \\
$p, p^{\prime}$-DDE & $\mathrm{ND}$ & $\mathrm{ND}$ & $\mathrm{ND}$ & $\mathrm{ND}$ & 0.50 \\
Dieldrin & $\mathrm{ND}$ & $\mathrm{ND}$ & $\mathrm{ND}$ & $\mathrm{ND}$ & 0.05 \\
Endrin & $\mathrm{ND}$ & $\mathrm{ND}$ & $\mathrm{ND}$ & $\mathrm{ND}$ & 0.01 \\
$p, p^{\prime}$-DDD & $0.147 \pm 0.146$ & $0.024 \pm 0.012$ & $\mathrm{ND}$ & $\mathrm{ND}$ & 0.50 \\
Endosulfan II & $0.399 \pm 0.399$ & $0.064 \pm 0.020$ & $\mathrm{ND}$ & $0.211 \pm 0.211$ & 0.10 \\
$p, p^{\prime}$-DDT & $0.012 \pm 0.012$ & $0.017 \pm 0.002$ & $0.166 \pm 0.155$ & $0.045 \pm 0.045$ & 0.50 \\
Endrin aldehyde & $\mathrm{ND}$ & $\mathrm{ND}$ & $\mathrm{ND}$ & $\mathrm{ND}$ & 0.01 \\
Endosulfan sulphate & $\mathrm{ND}$ & $\mathrm{ND}$ & $\mathrm{ND}$ & $\mathrm{ND}$ & 0.10 \\
Methoxychlor & $\mathrm{ND}$ & $\mathrm{ND}$ & $\mathrm{ND}$ & $\mathrm{ND}$ & 0.10 \\
\hline
\end{tabular}

Table 2. Mean concentration $(\mathrm{mg} / \mathrm{kg}$ ) of OCPs residues in vegetables from the selected cocoa farms (dry season).

\begin{tabular}{cccccc}
\hline OCPs & ISE & IRE & IDO & EMURE & MRL \\
\hline Alpha-BHC & ND & ND & ND & ND & 0.02 \\
Beta-BHC & ND & ND & ND & ND & 0.02 \\
Heptachlor & $0.029 \pm 0.029$ & $0.149 \pm 0.08$ & $0.099 \pm 0.021$ & $0.074 \pm 0.073$ & 0.02 \\
Aldrin & $0.063 \pm 0.032$ & $0.173 \pm 0.09$ & $0.145 \pm 0.067$ & $0.020 \pm 0.020$ & 0.05 \\
Gamma-BHC & $\mathrm{ND}$ & $0.005 \pm 0.004$ & $0.009 \pm 0.002$ & $0.002 \pm 0.001$ & 0.02 \\
Delta-BHC & $\mathrm{ND}$ & $0.086 \pm 0.018$ & $0.072 \pm 0.062$ & $0.009 \pm 0.009$ & 1.00 \\
Heptachlor epoxide & $\mathrm{ND}$ & $\mathrm{ND}$ & $0.020 \pm 0.020$ & $\mathrm{ND}$ & 0.02 \\
Endosulfan I & $0.059 \pm 0.002$ & $\mathrm{ND}$ & $\mathrm{ND}$ & $\mathrm{ND}$ & 0.10 \\
$p, p^{\prime}$-DDE & $\mathrm{ND}$ & $\mathrm{ND}$ & $\mathrm{ND}$ & $\mathrm{ND}$ & 0.50 \\
Dieldrin & $\mathrm{ND}$ & $\mathrm{ND}$ & $\mathrm{ND}$ & $\mathrm{ND}$ & 0.05 \\
Endrin & $\mathrm{ND}$ & $\mathrm{ND}$ & $\mathrm{ND}$ & $\mathrm{ND}$ & 0.01 \\
$p, p^{\prime}$-DDD & $0.136 \pm 0.001$ & $\mathrm{ND}$ & $\mathrm{ND}$ & $\mathrm{ND}$ & 0.50 \\
Endosulfan II & $0.227 \pm 0.003$ & $0.053 \pm 0.052$ & $0.052 \pm 0.051$ & $\mathrm{ND}$ & 0.10 \\
$p, p^{\prime}$-DDT & $0.053 \pm 0.022$ & $0.379 \pm 0.141$ & $0.063 \pm 0.041$ & $0.084 \pm 0.084$ & 0.50 \\
Endrin aldehyde & $\mathrm{ND}$ & $0.073 \pm 0.072$ & $0.081 \pm 0.081$ & $\mathrm{ND}$ & 0.01 \\
Endosulfan sulphate & $\mathrm{ND}$ & $\mathrm{ND}$ & $\mathrm{ND}$ & $\mathrm{ND}$ & 0.10 \\
Methoxychlor & $\mathrm{ND}$ & $\mathrm{ND}$ & $\mathrm{ND}$ & $\mathrm{ND}$ & 0.10 \\
\hline
\end{tabular}

ND: Not Detected. 
The results showed that $81.3 \%$ of the samples were contaminated with $p$, $p$-DDT, followed by aldrin (75.0\%); heptachlor, $\delta$-BHC and endosulfan II (62.5\%); endosulfan I, $p, p^{\prime}$-DDD (37.5\%); endrin aldehyde (18.8\%) and heptachlor epoxide (12.5\%). Few pesticides such as aldrin, endosulfan II, endrin aldehyde and heptachlor slightly exceeded their EU maximum residue limit [28] in the sampled vegetables. The Mean concentrations of aldrin reported in the study were found to be higher than those values reported by Bempah et al. [10] for vegetables in Ghana $(0.008-0.040 \mathrm{mg} / \mathrm{kg})$, while mean values of $\gamma-\mathrm{BHC}$ and $p$, $p^{\prime}$-DDT fell within the same range with Bempah et al. [10]. Endosulfans reported by Charan et al. [29] in vegetables from India were comparable with that of the present study.

To assess the risk of the pesticides contained in the vegetables on the consumers, estimated daily intake and hazard indices were calculated. Table 3 showed the estimated daily intake (EDI) and hazard indices (HI) of the OCPs residues from the selected cocoa farms in Ekiti State. The estimated daily intake values in bold exceeded their available daily intake (ADI) (Table 3). In Ise, EDI of two

Table 3. Estimated daily intake (EDI) and Hazard index (HI) of OCPs residues from the selected cocoa farms.

\begin{tabular}{|c|c|c|c|c|c|c|c|c|c|c|c|c|c|c|c|c|c|}
\hline \multirow{3}{*}{ OCPs } & \multirow{3}{*}{$\begin{array}{c}\text { WHO/IPCS } \\
\text { ADI } \\
\text { (mg/kg/day) }\end{array}$} & \multicolumn{4}{|c|}{ ISE } & \multicolumn{4}{|c|}{ IRE } & \multicolumn{4}{|c|}{ IDO } & \multicolumn{4}{|c|}{ EMURE } \\
\hline & & \multicolumn{2}{|c|}{ EDI } & \multicolumn{2}{|c|}{$\mathrm{HI}$} & \multicolumn{2}{|c|}{ EDI } & \multicolumn{2}{|c|}{$\mathrm{HI}$} & \multicolumn{2}{|c|}{ EDI } & \multicolumn{2}{|c|}{ HI } & \multicolumn{2}{|c|}{ EDI } & \multicolumn{2}{|c|}{$\mathrm{HI}$} \\
\hline & & $\mathrm{C}$ & A & $\mathrm{C}$ & $\mathrm{A}$ & $\mathrm{C}$ & A & $\mathrm{C}$ & A & $\mathrm{C}$ & A & $\mathrm{C}$ & A & $\mathrm{C}$ & A & $\mathrm{C}$ & A \\
\hline$\alpha$-BHC & 0.0005 & - & - & - & - & - & - & - & - & - & - & - & - & - & - & - & - \\
\hline$\beta$-BHC & 0.0005 & - & - & - & - & - & - & - & - & - & - & - & - & - & - & - & - \\
\hline Heptachlor & 0.0001 & $8.25 \mathrm{E}-5$ & $4.12 \mathrm{E}-5$ & 0.83 & 0.41 & $4.12 \mathrm{E}-4$ & $2.06 \mathrm{E}-4$ & 4.12 & 2.06 & $3.69 \mathrm{E}-4$ & $1.85 \mathrm{E}-4$ & 3.69 & 1.84 & $2.86 \mathrm{E}-4$ & $1.4 \mathrm{E} 3-4$ & 2.86 & 1.43 \\
\hline Aldrin & 0.0001 & $8.42 \mathrm{E}-4$ & 0.0004 & 8.42 & 4.20 & $4.79 \mathrm{E}-4$ & $2.39 \mathrm{E}-4$ & 4.79 & 2.39 & $5.83 \mathrm{E}-4$ & $2.92 \mathrm{E}-4$ & 5.83 & 2.92 & $1.87 \mathrm{E}-4$ & $9.35 \mathrm{E}-5$ & 1.87 & 0.94 \\
\hline$\gamma$-BHC & 0.0005 & - & - & - & - & $1.65 \mathrm{E}-5$ & $8.25 \mathrm{E}-6$ & 0.03 & 0.02 & $2.48 \mathrm{E}-5$ & $1.24 \mathrm{E}-5$ & 0.05 & 0.03 & $5.5 \mathrm{EE}-6$ & $2.75 \mathrm{E}-6$ & 0.01 & 0.005 \\
\hline$\delta$-BHC & 0.0005 & $1.1 \mathrm{E}-5$ & $5.5 \mathrm{E}-6$ & 0.02 & 0.01 & $1.38 \mathrm{E}-5$ & $6.88 \mathrm{E}-6$ & 0.03 & 0.01 & $4.18 \mathrm{E}-4$ & $2.09 \mathrm{E}-4$ & 0.84 & 0.42 & $2.48 \mathrm{E}-5$ & $1.24 \mathrm{E}-5$ & 0.05 & 0.03 \\
\hline $\begin{array}{l}\text { Heptachlor } \\
\text { epoxide }\end{array}$ & 0.0001 & $1.1 \mathrm{E}-5$ & $5.5 \mathrm{E}-6$ & 0.11 & 0.05 & $9.52 \mathrm{E}-4$ & $4.76 \mathrm{E}-4$ & 9.52 & 4.76 & $5.5 \mathrm{E}-5$ & $2.75 \mathrm{E}-5$ & 0.55 & 0.28 & - & - & - & - \\
\hline Endosulfan I & 0.00005 & $3.47 \mathrm{E}-4$ & $1.73 \mathrm{E}-4$ & 6.94 & 3.46 & $1.38 \mathrm{E}-5$ & $6.88 \mathrm{E}-6$ & 0.28 & 0.14 & - & - & - & - & $9.35 \mathrm{E}-5$ & $4.68 \mathrm{E}-5$ & 1.87 & 0.94 \\
\hline$p, p^{\prime}-\mathrm{DDE}$ & 0.0005 & - & - & - & - & - & - & - & - & - & - & - & - & - & - & - & - \\
\hline Dieldrin & 0.0001 & - & - & - & - & - & - & - & - & - & - & - & - & - & - & - & - \\
\hline Endrin & 0.0002 & - & - & - & - & - & - & - & - & - & - & - & - & & & & \\
\hline$p, p^{\prime}$-DDD & 0.0005 & $7.81 \mathrm{E}-4$ & $3.91 \mathrm{E}-4$ & 1.56 & 0.78 & $6.6 \mathrm{E}-5$ & $3.3 \mathrm{E}-5$ & 0.13 & 0.07 & - & - & - & - & - & - & - & - \\
\hline Endosulfan II & 0.00005 & $1.84 \mathrm{E}-3$ & $9.20 \mathrm{E}-4$ & 36.8 & 18.4 & $3.25 \mathrm{E}-4$ & $1.62 \mathrm{E}-4$ & 6.50 & 3.24 & $1.43 \mathrm{E}-4$ & $7.15 \mathrm{E}-5$ & 2.86 & 1.43 & $5.83 \mathrm{E}-4$ & $2.92 \mathrm{E}-4$ & 11.7 & 5.83 \\
\hline$p, p^{\prime}$-DDT & 0.0005 & $2.15 \mathrm{E}-4$ & $1.07 \mathrm{E}-4$ & 0.43 & 0.21 & $1.09 \mathrm{E}-3$ & $5.45 \mathrm{E}-4$ & 2.18 & 1.09 & $6.33 \mathrm{E}-4$ & $3.16 \mathrm{E}-4$ & 1.27 & 0.63 & $3.58 \mathrm{E}-4$ & $1.79 \mathrm{E}-4$ & 0.72 & 0.36 \\
\hline Endrin aldehyde & 0.0002 & - & - & - & - & $1.02 \mathrm{E}-4$ & $1.02 \mathrm{E}-4$ & 1.01 & 0.51 & $1.43 \mathrm{E}-4$ & $7.15 \mathrm{E}-5$ & 0.72 & 0.36 & - & - & - & - \\
\hline Methoxychlor & 0.10 & - & - & - & - & - & - & - & - & - & - & - & - & - & - & - & - \\
\hline
\end{tabular}

Bold and italic number exceeded their available daily intake. $\mathrm{C}=$ Children; $\mathrm{A}=$ Adult; $\mathrm{ADI}=$ Available daily intake; EDI = Estimated daily intake. 
Table 4. The combined health risk of the pesticides.

\begin{tabular}{ccc}
\hline Farm & Children & Adult \\
\hline ISE & 54.1 & 27.2 \\
IRE & 28.6 & 14.3 \\
IDO & 15.8 & 7.91 \\
EMURE & 19.1 & 9.54 \\
\hline
\end{tabular}

OCPs (heptachlor and $p, p^{\prime}$-DDT) exceeded their ADI. In Ido and Emure, four pesticides each (heptachlor, aldrin, endosulfan II and $p$, $p^{\prime}$-DDT) and (heptachlor, aldrin, endosulfan I and endosulfan II) exceeded their available daily intake respectively, while, heptachlor, heptachlor-epoxide, $p$, p'-DDT, endosulfan I and aldrin EDI in Ire for both children and adult exceeded their ADI. In general, the HI of heptachlor, endosulfan I, endosulfan II, $p, p^{\prime}$-DDD, aldrin, heptachlor-epoxide, $p, p$-DDT and endrin aldehyde for children were greater than 1 and therefore indicate likely potential health risk to children. For adult, aldrin, heptachlor, endosulfan I, endosulfan II, heptachlor-epoxide and $p$, $p^{\prime}$-DDT hazard indices also exceeded 1 and thus pose potential health risk.

The combined health risks for the pesticides were shown in Table 4. The combined health risks ranged from 15.8 to 54.1 and 7.91 to 27.2 for children and adult respectively. The total non-carcinogenic effect from the consumption of these vegetables is the sum of all the OCPs detected in the samples. The results thus suggested that the vegetable consumption in the study areas may pose potential non-carcinogenic health risks to consumers.

In this study, the risk assessment utilised the following assumptions regarding human exposure to the OCPs that the 1) sample (vegetable) was the only vegetable source, this assumption may overestimate health risks for vegetables as the only source of vegetables to the people in the area 2) concentrations of the pesticide remain unchanged during the whole exposure duration. This assumption could also lead to overestimation of potential risks contamination levels reduce over time. Therefore, the result of risk assessments should not be interpreted as accurate prediction of observed health outcomes, and it only provides means of screening for those pollutants that are of health significance, in order to prioritize research.

\section{Conclusion}

The study has provided the preliminary information on the levels of OCPs in vegetables (Senecio biafrae) from cocoa plantations in Ekiti State, South-western, Nigeria. The study not only confirmed the presence of pesticide residues in the samples, but also the levels of most residues which were generally above the EU maximum residue limits, suggesting that the vegetables were not totally safe for human consumption. Thus, there is need for regular and continuous monitoring of pesticide residues, especially in food that form a bulk of daily diet of many 
Nigerians. Based on the outcome of the study, it is becoming imperative for cocoa farmers to adopt the integrated pest management techniques in processing their crops.

\section{Conflicts of Interest}

The authors declare no conflicts of interest regarding the publication of this paper.

\section{References}

[1] Dhellot, J.R., Matouba, E., Maloumbi, M.G., Nzikou, J.M., Safou-Ngoma, D.G., Linder, M., Desobry, S. and Parmentier, M. (2006) Extraction, Chemical Composition and Nutritional Characterization of Vegetables Oils: Case of Amaranthus hy bridus (var 1 and 2) of Congo Brazzaville. African Journal of Biotechnology, 5, 1095-1101.

[2] Onwordi, C.T., Anuoluwa M.O. and Adedoja D.W. (2009) The Proximate and Mineral Compositions of Three Leafy Vegetables Commonly Consumed in Lagos, Nigeria. African Journal of Pure and Applied Chemistry, 3, 102-107.

[3] Anjorin, T.S., Ikokoh, P. and Okolo, S. (2010) Mineral Composition of Moringa oleifera Leaves, Pods and Seed from Two Regions in Abuja, Nigeria. International Journal of Agriculture and Biology, 7, 431-434.

[4] Stadlmayr, B., Charrondière, U.R. and Burlingame, B. (2013) Development of a Regional Food Composition Table for West Africa. Food Chemistry, 140, 443-446. https://doi.org/10.1016/j.foodchem.2012.09.107

[5] Orech, F.O., Akenga T., Ochara, J., Fruits, H. and Aagard-Hansen, J. (2005) Potential Toxicity of Some Traditional Leafy Vegetables Consumed in Nyang Division, Western Kenya. African Journal of Food Agriculture Nutrition and Development, 5, 40-42.

[6] Dairo, F.A.S. and Adanlawo, I.G. (2007) Nutritional Quality of Grassocephalum crepidioides and Senecio biafrae. Pakistan Journal of Nutrition, 6, 35-39. https://doi.org/10.3923/pjn.2007.35.39

[7] Fosu-Mensah B.Y., Okoffo, E.D., Darko, G. and Gordon, C. (2016) Assessment of Organochlorine Pesticide Residues in Soils and Drinking Water Sources from Cocoa Farms in Ghana. SpringerPlus, 5, 869-882. https://doi.org/10.1186/s40064-016-2352-9

[8] Adebooye, O.C. (2004) Solanecio Biafrae (Oliv. \& Hiern). In: Grubben, G.J.H. andDenton, O.A., Eds., Plant Resources of Tropical Africa, Backhuys Publishers, Leiden, 169.

[9] Ibigbami, O.A., Aiyesanmi, A.F., Adeyeye, E.I., Adebayo, A.O. and Aladesanwa, R.D. (2017) Quantitative Study of Multi-Residue Levels of Organochlorine Pesticides in Soils of Cocoa Farms in Ekiti State, South Western Nigeria. International Journal of Scientific and Engineering Research, 8, 1024-1037.

[10] Bempah, C.K., Donkor, A.K., Yeboah, P.O., Dubey, B. and Osei-Fosu, P. (2011) A Preliminary Assessment of Consumer Exposure to Organochlorine Pesticides in Fruit and Vegetables and the Potential Health Risk in Accra Metropolis, Ghana. Food Chemistry, 128, 1058-1065. https://doi.org/10.1016/j.foodchem.2011.04.013

[11] Abou-Arab, A.A.K. (1999) Behaviour of Pesticides in Tomatoes during Commercial and Home Preparation. Food Chemistry, 65, 509-514.

https://doi.org/10.1016/S0308-8146(98)00231-3 
[12] Guler, G.O., Cakmak, Y.S., Dagli, Z., Aktumsek, A. and Ozparlak, H. (2010) Organochlorine Pesticide Residues in Wheat from Konya Region, Turkey. Food and Chemical Toxicology, 48, 1218-1221. https://doi.org/10.1016/j.fct.2010.02.013

[13] Gao, H.J., Jiang, X., Wang, F., Wang, D.Z. and Bian, Y.R. (2005) Residual Levels and Bioaccumulation of Chlorinated Persistent Organic Pollutants (POPs) in Vegetables from Suburb of Nanjing, People's Republic of China. Bulletin of Environmental Contamination and Toxicology, 74, 673-680.

https://doi.org/10.1007/s00128-005-0636-9

[14] Owago, O.J., Qi, S., Xing, X.L., Yuan, Z. and Sylvie, M.A. (2009) Residues of Organochlorine Pesticides in Vegetables from Deyang and Yanting Areas of the Chengdu Economic Region, Sichuan Province, China. Journal of American Science, 5, 91-100.

[15] Bempah, C.K., Buah-Kwofie, A., Enimil, E., Blewu, B. and Agyei-Martey, G. (2012) Residues of Organochlorine Pesticides in Vegetables Marketed in Greater Accra Region of Ghana. Food Control, 25, 537-542.

https://doi.org/10.1016/j.foodcont.2011.11.035

[16] Kolani, L., Mawussi, G. and Sanda, K. (2016) Assessment of Organochlorine Pesticide Residues in Vegetable Samples from Some Agricultural Areas in Togo. American Journal of Analytical Chemistry, 7, 332-341. https://doi.org/10.4236/ajac.2016.74031

[17] Quitana, P.J.E., Delfino, R.J., Korrick, S., Ziogas, A., Kutz, F.W., Jones, E.L., Laden, F. and Garschick, E. (2004) Adipose Tissue Levels of Organochlorine Pesticides and Polychlorinated Biphenyls and Risk of Non-Hoggkins Lymphoma. Environmental Health Perspectives, 112, 854-861. https://doi.org/10.1289/ehp.6726

[18] Walorczik (2008) Dermal Absorption of Pesticides: Toxicology of Pesticides, World Health Organization Regional Office for Europe, Copenhagen, Denmark. European Cooperation on Environmental Health Aspects of the Control of Chemicals, Interim Document 9, 41-53.

[19] United States Environmental Protection Agency (USEPA) (2000) Test Methods for Evaluating Solid Waste. 3rd Edition, USEPA SW-846, Update IVB' Chapter 4, Organic Analytes, USEPA, Washington DC.

[20] EPA US (1996) Integrated Risk Information System. United States Environmental Protection Agency. Off. Health Environ. Assess., Washington DC.

[21] World Health Organization WHO (1997) Guideline for Predicting Dietary Intake of Pesticide Residues (Revised). Global Environmental Monitoring System. Food Contamination and Assessment Programme (GEMS/Food) in Collaboration with Codex Committee on Pesticide Residues.

[22] FAO (2007) FAO Food Balance Sheets. Nigeria Vegetables Consumption 1992-2007. http://knoema.com

[23] WHO/IPCS (2009) Inventory of IPCS and Other WHO Pesticide Evaluations and Summary of Toxicological Evaluations Performed by the Joint Meeting on Pesticide Residues (JMPR) through 2009.

[24] Wang, H.S., Sthiannopkao, S., Du, J., Chen, Z.J., Kim, K.W., Yasin, M.S.M., Hashim, J.H., Wong, C.K.C. and Wong, M.H. (2011) Daily Intake and Human Risk Assessment of Organochlorine Pesticides (OCPs) Based on Cambodian Market Basket Data. Journal of Hazardous Materials, 192, 1441-1449. https://doi.org/10.1016/j.jhazmat.2011.06.062

[25] Saha, N. and Zaman, M.R. (2013) Evaluation of Possible Risks of Heavy Metals by Consumption of Foodstuffs Available in the Central Market of Rajshahi City, Bang- 
ladesh. Environmental Monitoring and Assessment, 185, 3867-3878.

https://doi.org/10.1007/s10661-012-2835-2

[26] United States Environmental Protection Agency US EPA (2000) Supplementary Guidance for Conducting Health Risk Assessment of Chemical Mixtures. US Environmental Protection Agency, Risk Assess. Forum Tech. Panel. Off. EPA/630/R-00/002.

[27] Reffstrup, T.K., Larsen, J.C. and Meyer, O. (2010) Risk Assessment of Mixtures of Pesticides Current Approaches and Future Strategies. Regulatory Toxicology and Pharmacology, 56, 174-192. https://doi.org/10.1016/j.yrtph.2009.09.013

[28] European Union Commission Regulation (2005) No 396/2005 of the European Parliament and of the Council of 23 February 2005 on Maximum Residue Levels of Pesticides in or on Food and Feed of Plant and Animal Origin and Amending Council Directive 91/414/E-Text with EEA Relevance.

[29] Charan, P.D., Ali, S.F., Kachhawa, Y. and Sharma, K.C. (2010) Monitoring of Pesticide Residues in Farmgate Vegetables of Central Aravalli Region of Western India. American-Eurasian Journal of Agricultural and Environmental Science, 7, 255-258. 